\title{
The Research on Accounting Information Based on Computerized Accounting in the Financial Management
}

\author{
Yan Wang ${ }^{1, a^{*}}$ \\ ${ }^{1}$ Department of economics and management, Tianjin Electronic Information College, Tianjin, \\ 300350, China \\ a ywang@126.com \\ ${ }^{*}$ The corresponding author
}

Keywords: Computerized accounting; accounting information; the financial management; information technology

\begin{abstract}
In recent years, due to the rapid development and widespread use of computer technology, computerized accounting has become the development trend of accounting work. Accounting computerization has the advantages of fast operation, large storage capacity, fast retrieval speed and accurate data analysis, and is widely used in enterprise financial management. In this paper, the accounting computerization and the concept of accounting information, characteristics and the relationship with enterprise informatization are deeply expounded and analyzed. The continuous development of computerized accounting has greatly promoted the growth of many related software industries. In the society, a contingent of accounting, accounting and financial software development has been preliminarily formed. Through the elaboration and analysis of this article, it will provide some reference and research foundation for the further development of accounting computerization and accounting informatization.
\end{abstract}

\section{Introduction}

Computerized accounting refers to the accounting software prepared by the professional staff, by the accounting staff and the relevant operators to operate the computer to replace the artificial work for completing the accounting work, that is to say, it is a process of using computer to replace manual accounting, counting, reimbursement, analysis and application of all kinds of accounting information, which consists of the organization and planning of computerized accounting work, the establishment of computerized accounting information system, the formation of computerized accounting management system, the training of accounting personnel, the management of computerized accounting information system, computerized auditing, etc[1,2]. The establishment of computerized accounting network system can quickly realize the sharing of data and delivery of information at home and abroad quickly, not only meet the needs of management information for units, but also provide good opportunities of carrying out management, analysis, forecasting and decision-making using the internal accounting information and external information for the financial management personnel, accounting management personnel, analysis personnel and unit leaders.

\section{The Characteristics of Computerized Accounting}

Data accuracy is improved. More accurate and more logical are the greatest strengths of computers, so the computerized software is used to process the data, which will make the data more accurate and more logical. The computer will point out the mistake and the wrong voucher won't be saved. Under the computerized accounting system, reduced errors caused by human factors and improved the quality of accounting.

Data processing speed is improved. Computer can process the data at a high speed and the 
computerized software can improve the speed of processing data, which has increased the efficiency of processing data and enhanced the timeliness of accounting information. Simultaneously, accountant can use computerized software get the data themselves want to query or calculate, which reduced to a great extent accountant's work intensity.

Date storage specialization. The accounting information data stored in the magnetic medium is the same as other electronic information data, both of them have the characteristics of convenient storage, deletion and modification without leaving traces and so on. But it is precisely this characteristic, at the same time, it brings great threat to the security and reliability of accounting information data, it also makes in the future the audit trail became very difficult.

The programming of internal control. In the manual accounting model, managers can form a system of internal control through the division of functions and the division of labor, integrate with a system that relies on vouchers, books, and statements, to ensure the accuracy and safety of accounting information. After the implementation of computerized accounting, an effective control system that has been placed under the manual accounting environment, the security and reliability of the hardware and software working environment must be carefully considered, and make some very strict measures, to ensure that a set of accounting data such as vouchers, accounting books and statements can be true and accurate[3].

\section{The concept and Characteristics of Accounting Informatization}

Accounting information is the use of modern information technology, such as computers, networks, communications and so on, the traditional accounting model was reconstructed, after reconstructing the postmodern accounting model, Through the extensive use and deepening of the development of accounting information resources, the establishment of accounting and technology difficult, integrated, open and modern accounting information system, to improve the usefulness of accounting information in optimizing the allocation of resources, and to promote economic development and social progress. Accounting informatization is not only the component part of enterprise informatization and national economy informatization, but also the foundation of its development $[4,5]$.

Accounting informatization has the following characteristics:

Universality. All fields of accounting, such as accounting theory, accounting management, accounting work and accounting education, should be comprehensively applied in modern information technology.

Integration. The accounting informatization will restructure the traditional business processes and accounting organizations to support data banks and virtual enterprises. The starting point and the end point of this process are to realize the integration of information. The integration of information consists of three parts: (1) Realize the integration of information in the accounting field; (2) Realize the integration of Finance and business within the enterprise organization; (3) We should establish the information network between the enterprise and the external interested parties, and realize the integration of internal and external information of the whole organization.

Dynamic. Dynamic, also known as real synchronization or sexual timing. The dynamic of accounting informatization in time is manifested as: (1)Collecting accounting data is dynamic; (2) Dealing with accounting data is real time; (3) Accounting data acquisition and processing of real-time and dynamic.

Gradualness. The modern information technology has the subjective initiative to reconstruct the accounting model. However, such a dynamic embodiment is a gradual process. Specific should be divided into three steps: (1)The traditional accounting model should adapt to the modern information technology; (2) the traditional accounting model and modern information technology should be adapted to each other; (3) Using modern information technology to reconstruct the traditional accounting model, To form a modern accounting information system, the implementation of 
accounting information, accounting management information, accounting decision-making support of the overall accounting informatization.

\section{The Relationship between Accounting Computerization, Accounting Informatization and Enterprise Informatization}

Computerized accounting is the foundation of the development of accounting information, accounting information is the inevitable trend of the development of accounting computerization[6]. Whether it is the development of accounting computerization or the development of accounting information, it is to meet the needs of enterprise information for accounting information subsystem, and ultimately to enhance the overall competitiveness of enterprises. However, because of the obvious differences in the theoretical basis, guiding ideology and technical means, the role of the two in the construction of enterprise informatization is also different. Computerized accounting is actually passively adapted to this requirement, although it helps the development of enterprise informatization to some extent, it helps the accounting information subsystem to link with other subsystems of the enterprise, the accounting data is compared to the manual bookkeeping stage more accurately and transfer more quickly and more convenient, but due to some problems of its own, so the role of the information construction of enterprises is still limited. Accounting information is different, is actively adapt to this requirement. Because the accounting information put forward later, so when it came into being, it was regarded as a subsystem of the whole enterprise information system, and it was organically combined with other subsystems. In this way, not only can the financial information be more widely utilized, but also the financial accounting function can be brought into play, and it can also provide decision support for the enterprise, Putting the management function of accounting in the whole enterprise information system environment, play the role of accounting management, the development of accounting information can fully meet the needs of enterprise information construction.

\section{Conclusion}

Accounting computerization and accounting informatization are different stages of development when accounting enters the information age, they are the comprehensive disciplines that arise from the intersection of computer and information network technology, accounting, management and economics. This article embarks from the accounting computerization and the accounting informationization background, and characteristics of computerized accounting and accounting informatization are expounded systematically, and the relation between the two and enterprise informatization is expounded. Computerized accounting and accounting information represent new accounting ideas and concepts, is the combination of traditional accounting theory and modern information technology and computer network technology, is the inexorable trend of modern accounting development, and will continue to promote the steady development of China's accounting informatization.

\section{Reference}

[1] Zangxiu Qing, He Yufen. Technology security and defense of network accounting. Accounting communications. 2009,2:46-52.

[2] Bushman, R.A Smith. Transparency, Financial Accounting Information and Corporate Governance. FRBNY Economic Policy Review. 2003,3:15-22.

[3] Microstructural Evolution and Thermal Stability of Ultra-fine Grained Al-4Mg Alloy by Equal Channel Angular Pressing. Journal of Materials Science \& Technology,2014,(03):46-58.

[4] Shao Dan.From Accounting Computerlization to Modern Accounting Information System. China Management Informationlization. 2006,2:12-20. 
[5] Shan Binglei. The Security-risks and prevention of Network Accounting Information System. Chinese Enterprise Accounting of Villages and towns. 2009,5:89-98.

[6] N Hupert, BC Amick, AH Fossel,et al.. Upper extremity musculoskeletal symptoms and functional impairment associated with computer use among college students[J].Journal of Prevention Assessment \& Rehabilitation, 2014,23(2): 85-93. 